\title{
Parotidectomy outcomes, diagnosis and complications on pediatric patients; Twelve years of experiences in a tertiary care center
}

\author{
Oğuz Kuşcu, Bahar Kayahan, Övsen Önay, Rıza Önder Günaydın, Mehmet Umut Akyol \\ Department of Otolaryngology, Head and Neck Surgery, Hacettepe University Faculty of Medicine, Ankara, Turkey. \\ E-mail: drkuscu@gmail.com \\ Received: 15 September 2015, Revised: 31 March 2016, Accepted: 12 May 2016
}

SUMMARY: Kuşcu O, Kayahan B, Önay Ö, Günaydın RÖ, Akyol MU. Parotidectomy outcomes, diagnosis and complications on pediatric patients; Twelve years of experiences in a tertiary care center. Turk J Pediatr 2016; 58: $132-135$.

The aim of this study is to evaluate parotid masses management in pediatric population. From June 2002 to December 2014, 13 patients under the age of 18 with parotid tumors were treated via surgery at Hacettepe University Department of Otorhinolaryngology. Information on patients' demographics, clinical and histopathologic tumor characteristics and treatment modalities with results was obtained from medical records, retrospectively. The age was ranging between $8-17$ years. Ten $(76.9 \%)$ patients had benign tumors and 8 $(61.5 \%)$ of them were pleomorphic adenoma. One case had chronic sialadenitis with sialolithiasis and one patient had fluoride follicular hyperplasia. Three patients had malignant tumors; two of them were adenoid cystic carcinoma and one case of malignant melanoma metastasis. Twelve cases had undergone partial parotidectomy. Only one total parotidectomy was performed which was the patient with malignant melanoma. None of the patients had major complications or facial nerve palsy. During the 3 years follow up period, recurrence or Frey syndrome had not been detected but the case with malignant melanoma had distant metastasis during the follow up time.

Although pediatric parotid masses are unusual, they can represent a variety of pathological diagnoses, including malignancy. Parotidectomy remains the mainstay of treatment and surgical experience is needed for low complication rates especially in children.

Key words: parotidectomy, pediatric patient, pleomorphic adenoma, adenoid cystic carcinoma.

Parotid masses in pediatric population can represent various pathological diagnoses such as inflammatory diseases or parotid involvement of tumors ${ }^{1}$. Diagnosis and treatment could be challenging, especially in children ${ }^{2}$. It is essential to evaluate the pediatric population separately from adults and the predictive factors should be addressed. The aim of this study is to define the management of pediatric parotid masses.

\section{Material and Methods \\ Retrospective data was collected and there}

were 13 patients younger than 18 years who underwent partial or total parotidectomy at the Hacettepe University Department of Otorhinolaryngology between 2002 and 2014. Medical records were evaluated in terms of patients' demographic data, symptoms, surgical management, histopathologic diagnosis and postoperative complications. This retrospective study was accepted by the Hacettepe University Ethics Committee, and informed consent forms were obtained from each case and family. All patients had preoperative imaging including ultrasonography (US) and/or magnetic resonance 
imaging (MRI). Preoperative histopathologic investigation including fine-needle aspiration cytology (FNAC) was performed on all patients. Partial or total parotidectomy was performed with facial nerve monitoring.

\section{Results}

There were 13 patients who underwent parotidectomy (12 cases partial, one case total) to treat parotid masses. The age range was between 8-17 years. There were 9 female and 4 male in our study. $45.1 \%$ of lesions were located on right and $54.9 \%$ were located on the left gland.

Painless parotid mass was observed in all patients, two cases showed mass in the preauricular region and 11 cases had mass in the tail of parotid gland. Ten patients $(76.9 \%)$ had benign lesions and $8(61.5 \%)$ of them were pleomorphic adenoma. Benign tumors of parotid gland like pleomorphic adenoma were seen as masses with well defined boundary and full of contrast on MRI. Histopathologic view of pleomorphic adenoma is well encapsulated mass with tubuloglandular structures and myxomatous stroma. The other cases with benign lesions had chronic sialoadenitis with sialolithiasis and fluoride follicular hyperplasia (Table I). Three cases had malignant parotid tumors, including adenoid cystic carcinoma (ACC) (2 cases) and malignant melanoma metastasis (one case). Two cases with the diagnosis of ACC were treated with partial parotidectomy and they did not have any adjuvant therapy, their follow-up is still going on as free of recurrence. One case which was diagnosed as malignant melanoma (MM) metastasis that came from skin MM was excised with clear surgical margin two years ago and was evaluated in terms of primary region and neck metastasis with MRI before the treatment. Any lesions in primary skin area or clinically lymph node were not detected. Total parotidectomy with elective neck dissection was performed. After the surgery the patient had adjuvant chemoradiotherapy. During the follow-up period there was no lymph node metastasis but he had distant metastasis.

When it comes to FNAC reports, it has $100 \%$ sensitivity and $80 \%$ specificity for benign parotid tumors. Table I summarizes demographic features of patients, preoperative management, histopathological results and the management of follow-up period.

There were no minor postoperative complications such as wound infection, saliva leakage, hematoma or seroma. Also, there was no transient or permanent facial nerve palsy or paralysis in this study. During the 3 years of follow up period, neither recurrence nor Frey syndrome had been detected. There was no patient who complained about symptoms of Frey Syndrome such as flushing or sweating after eating. That is why starch-iodine test was not applied on any of the patients.

\section{Discussion}

Slowly enlarging painless mass is the most common symptom of parotid tumors. Painless mass is also seen in inflammatory diseases of parotid gland and/or regional lymph nodes. So diagnosis of a mass in the parotid region in children contributes a challenge ${ }^{3,4}$. Woods et al. ${ }^{5}$ reported that symptoms such as pain, facial nerve palsy and rapid growth of tumors are more frequently found in malignant parotid tumors. However, they were not seen in any of the patients in our series.

Decision making about parotid mass is most challenging and an urgent diagnosis and proper treatment are essential. Both US and MRI have an important role in the preoperative evaluation ${ }^{6,7}$. In our study, we used US and/ or MR in all patients. MRI has important role for surgical planning and to determine histopathologic type of benign parotid tumors. That is why FNAC is not necessary for all patients since MRI usually provide us a preoperative diagnosis ${ }^{8,9}$ especially in benign tumors. However, imaging studies could not distinguish a benign tumor from a low-grade malignant lesion; FNAC was the most useful method to diagnose pathologies preoperatively.

Parotidectomy seems to be a gold standard modality and mostly used technique to provide surgical resection of the tumor with no residue. It is now generally accepted that partial parotidectomy is the minimal surgery that has to be applied in the primary modality of treatment for benign parotid lesion ${ }^{10,11}$. Recurrence rate for pleomorphic adenoma in children is higher than that in adult population ${ }^{12}$ because conservative surgery is mostly preferred by the surgeon in children. 
Table I. Demographic Features of the Patients

\begin{tabular}{|c|c|c|c|c|c|c|c|c|}
\hline Case & Age & Sex & $\begin{array}{c}\text { Pre-op } \\
\text { management }\end{array}$ & FNAC & $\begin{array}{l}\text { Histopat. } \\
\text { result }\end{array}$ & Surgery & Follow-up & Recurrence \\
\hline $\begin{array}{l}\text { Case } \\
1\end{array}$ & 17 & $\mathrm{~F}$ & US / MRI & PA & PA & $\begin{array}{c}\text { Partial } \\
\text { parotidectomy }\end{array}$ & $\begin{array}{c}\text { Physical } \\
\text { examination }\end{array}$ & $\begin{array}{c}\text { No } \\
\text { Recurrence }\end{array}$ \\
\hline $\begin{array}{l}\text { Case } \\
2\end{array}$ & 10 & $\mathrm{~F}$ & US & PA & PA & $\begin{array}{l}\text { Partial } \\
\text { parotidectomy }\end{array}$ & $\begin{array}{c}\text { Physical } \\
\text { examination }\end{array}$ & $\begin{array}{c}\text { No } \\
\text { Recurrence }\end{array}$ \\
\hline $\begin{array}{l}\text { Case } \\
3\end{array}$ & 16 & $\mathrm{~F}$ & MRI & PA & PA & $\begin{array}{c}\text { Partial } \\
\text { parotidectomy }\end{array}$ & $\begin{array}{l}\text { Physical } \\
\text { examination }\end{array}$ & $\begin{array}{c}\text { No } \\
\text { Recurrence }\end{array}$ \\
\hline $\begin{array}{l}\text { Case } \\
4\end{array}$ & 13 & M & US / MRI & PA & PA & $\begin{array}{c}\text { Partial } \\
\text { parotidectomy }\end{array}$ & $\begin{array}{c}\text { Physical } \\
\text { examination }\end{array}$ & $\begin{array}{c}\text { No } \\
\text { Recurrence }\end{array}$ \\
\hline $\begin{array}{l}\text { Case } \\
5\end{array}$ & 15 & M & US / MRI & $\begin{array}{c}\text { Non- } \\
\text { diagnostic }\end{array}$ & $\mathrm{FFH}$ & $\begin{array}{c}\text { Partial } \\
\text { parotidectomy }\end{array}$ & $\begin{array}{c}\text { Physical } \\
\text { examination }\end{array}$ & $\begin{array}{c}\text { No } \\
\text { Recurrence }\end{array}$ \\
\hline $\begin{array}{l}\text { Case } \\
6\end{array}$ & 11 & $\mathrm{~F}$ & US & PA & PA & $\begin{array}{c}\text { Partial } \\
\text { parotidectomy }\end{array}$ & $\begin{array}{l}\text { Physical } \\
\text { examination }\end{array}$ & $\begin{array}{c}\text { No } \\
\text { Recurrence }\end{array}$ \\
\hline $\begin{array}{l}\text { Case } \\
7\end{array}$ & 8 & $\mathrm{~F}$ & US/MRI & $\begin{array}{c}\text { Non- } \\
\text { diagnostic }\end{array}$ & ACC & $\begin{array}{c}\text { Partial } \\
\text { parotidectomy }\end{array}$ & MRI & $\begin{array}{c}\text { No } \\
\text { Recurrence }\end{array}$ \\
\hline $\begin{array}{l}\text { Case } \\
8\end{array}$ & 17 & $\mathrm{~F}$ & MRI & $\begin{array}{c}\text { Non- } \\
\text { diagnostic }\end{array}$ & Chr. st. & $\begin{array}{c}\text { Partial } \\
\text { parotidectomy }\end{array}$ & $\begin{array}{l}\text { Physical } \\
\text { examination }\end{array}$ & $\begin{array}{c}\text { No } \\
\text { Recurrence }\end{array}$ \\
\hline $\begin{array}{l}\text { Case } \\
9\end{array}$ & 8 & M & US/MRI & $\mathrm{MM}$ & $\mathrm{MM}$ & $\begin{array}{c}\text { Total } \\
\text { parotidectomy }\end{array}$ & MRI & $\begin{array}{c}\text { No } \\
\text { Recurrence } \\
\text { distant } \\
\text { metastasis }\end{array}$ \\
\hline $\begin{array}{l}\text { Case } \\
10\end{array}$ & 14 & $\mathrm{~F}$ & US/MRI & PA & PA & $\begin{array}{c}\text { Partial } \\
\text { parotidectomy }\end{array}$ & $\begin{array}{l}\text { Physical } \\
\text { examination }\end{array}$ & $\begin{array}{c}\text { No } \\
\text { Recurrence }\end{array}$ \\
\hline $\begin{array}{l}\text { Case } \\
11\end{array}$ & 9 & $\mathrm{~F}$ & US/MRI & $\begin{array}{c}\text { Non- } \\
\text { diagnostic }\end{array}$ & ACC & $\begin{array}{c}\text { Partial } \\
\text { parotidectomy }\end{array}$ & MRI & $\begin{array}{c}\text { No } \\
\text { Recurrence }\end{array}$ \\
\hline $\begin{array}{l}\text { Case } \\
12\end{array}$ & 13 & $\mathrm{~F}$ & US/MRI & PA & PA & $\begin{array}{c}\text { Partial } \\
\text { Parotidectomy }\end{array}$ & MRI & $\begin{array}{c}\text { No } \\
\text { Recurrence }\end{array}$ \\
\hline $\begin{array}{l}\text { Case } \\
13\end{array}$ & 15 & M & US/MRI & PA & PA & $\begin{array}{l}\text { Partial } \\
\text { parotidectomy }\end{array}$ & MRI & $\begin{array}{c}\text { No } \\
\text { Recurrence }\end{array}$ \\
\hline
\end{tabular}

ACC: adenoid cystic carcinoma; Chr.st:Chronic Sialoadenitis; FFH: fluoride follicular hyperplasia; FNAC: fine needle aspiration biopsy; MM: malignant melanoma ; MRI: magnetic resonance imaging; PA: pleomorphic adenoma; US: ultrasound

We treated parotid tumors by partial and total parotidectomy according to tumor localization. Facial nerve paralysis or paresis is commonly seen after the parotidectomy. In adults, reported rates of post-parotidectomy facial nerve paresis range between $9 \%$ and $60 \%^{13}$. In this study, there was no facial nerve paralysis either transient or permanent because of meticulous dissection of facial nerve.

In literature, the most common benign tumor of parotid gland in children is pleomorphic adenoma and mucoepidermoid carcinoma is the most commonly seen malignant tumor, and there is a female to male predominance ${ }^{14}$. We agreed with the literature about female to male predominance; there were 9 female and 4 male. Mucoepidermoid carcinoma in pediatric age has predominance in case of malignant tumors and it is commonly seen as low or intermediate histological grade where as in adult age it is commonly seen as high-grade tumor ${ }^{15}$. We found that the most benign tumor of parotid gland was pleomorphic adenoma but in our series 2 of 3 malignant tumors were ACC and one of them was malignant melanoma metastasis. This finding is in direct disagreement with previously published reports. Malignant parotid tumor usually requires a combination of treatment modalities besides surgery. If the tumors were in the early stage or low grade, parotidectomy alone was enough ${ }^{16}$. Two of our patients with low-grade ACC were treated with parotidectomy alone which did not show recurrence during the five-year followup period and they have been followed with MRI. Patient with MM was treated by total 
parotidectomy with elective neck dissection with facial nerve preservation.

The role of postoperative radiation therapy in treatment of childhood salivary gland tumors remains controversial. Indications such as residual disease, high-grade tumors, perineural and vascular invasion, soft tissue invasion, positive margins or nodal metastasis require adjuvant radiotheraphy ${ }^{17}$. In our series, only one case which was diagnosed as malignant melanoma metastasis had adjuvant chemotherapy and radiotherapy.

\section{Conclusion}

Parotid masses in children are uncommon and showing different pathologic diagnoses. Diagnosis, treatment and decision making, bring about the challenge in the head and neck region. Total or partial parotidectomy is the gold standard treatment for salivary gland neoplasms. Surgical experience is needed for low complication rates especially in children.

\section{REFERENCES}

1. Guzzo M, Ferrari A, Marcon I, et al. Salivary gland neoplasms in children: the experience of the Istituto Nazionale Tumori of Milan. Pediatr Blood Cancer 2006; 47: 806-810.

2. Weiss I, O TM, Lipari BA, et al. Current treatment of parotid hemangiomas. Laryngoscope 2011; 121 : $1642-1650$

3. Ethunandan M, Ethunandan A, Macpherson D, et al. Parotid neoplasms in children: experience of diagnosis and management in a district general hospital. Int $\mathrm{J}$ Oral Maxillofac Surg 2003; 32: 373-377.

4. Shikhani AH, Johns ME. Tumors of the major salivary glands in children. Head Neck Surg 1988; 10: 257-263.

5. Woods JE, Chong GC, Beahrs OH. Experience with 1,360 primary parotid tumors. Am J Surg 1975; 130: 460-462.
6. Sodhi KS, Bartlett M, Prabhu NK. Role of high resolution ultrasound in parotid lesions in children Int J Pediatr Otorhinolaryngol 2011; 75; 1353-1358.

7. Liu ES, Bernstein JM, Sculerati N, et al. Fine needle aspiration biopsy of pediatric head and neck masses. Int J Pediatr Otorhinolaryngol 2001; 60: 135-140

8. Ali NS, Akhtar S, Junaid M, et al. Diagnostic accuracy of fine needle aspiration cytology in parotid lesions. ISRN Surg 2011; 2011: 721525.

9. Howlett DC. Diagnosing a parotid lump: fine needle aspiration cytology or core biopsy? Br J Radiol 2006; 79: 295-297.

10. Rodriguez $\mathrm{KH}$, Vargas S, Robson C, et al. Pleomorphic adenoma of the parotid gland in children. Int J Pediatr Otorhinolaryngol 2007; 71: 1717-1723.

11. Lin CC, Tsai MH, Huang CC, et al. Parotid tumors: a 10-year experience. Am J Otolaryngol 2008; 29: 94-100.

12. da Cruz Perez DE, Pires FR, Alves FA, et al. Salivary gland tumors in children and adolescents: a clinicopathologic and immunohistochemical study of fifty-three cases. Int J Pediatr Otorhinolaryngol 2004; 68: 895-902.

13. Gaillard C, Périé S, Susini B, et al. Facial nerve dysfunction after parotidectomy: the role of local factors. Laryngoscope 2005; 115: 287-291.

14. Liu B, Liu JY, Zhang WF, et al. Pediatric parotid tumors: clinical review of 24 cases in a Chinese population. Int J Pediatr Otorhinolaryngol 2012; 76: 1007-1011.

15. Al-Mazrou KA. Pediatric parotidectomy. Indications and complications. Saudi Med J 2007; 28: 1218-1221.

16. Shapiro NL, Bhattacharyya N. Clinical characteristics and survival for major salivary gland malignancies in children. Otolaryngol Head Neck Surg 2006; 134: 631-344.

17. Slevin N. Frankenthaler R. The role of radiotherapy in the management of salivary gland cancer. In: McGurk $\mathrm{M}$, Renahan AG (ed). Controversies in the management of Salivary Gland Disease. Oxford: Oxford University Press; 2001: 163-172. 